\title{
Measurement of Receptor-Activated Phosphoinositide Turnover in Rat Brain: Nonequivalence of Inositol Phosphate and CDP-Diacylglycerol Formation
}

\author{
Anne M. Heacock, Edward B. Seguin, and Bernard W. Agranoff \\ Neuroscience Laboratory, University of Michigan, Ann Arbor, Michigan, U.S.A.
}

\begin{abstract}
Two methods for the measurement of receptoractivated phosphoinositide turnover were evaluated for their degree of correspondence in slices of rat brain; they involved the $\mathrm{Li}^{+}$-dependent accumulations of either $\left[{ }^{3} \mathrm{H}\right]-$ inositol-labeled inositol phosphates or $\left[{ }^{3} \mathrm{H}\right]$ cytidine-labeled CDP-diacylglycerol. In contrast to the expectation that the ratio of these two responses would remain approximately constant, varying degrees of correspondence were obtained. The two extremes are exemplified by carbachol, which elicited large increases in both inositol phosphate and CDP-diacylglycerol labeling, and endothelin, which gave a robust inositol phosphate response with little or no accumulation
\end{abstract}

of ${ }^{3} \mathrm{H}$-CDP-diacylglycerol. No instance of the presence of the latter response in the absence of ${ }^{3} \mathrm{H}$-inositol phosphate accumulation was observed. Measurement of ${ }^{3} \mathrm{H}$-CDP-diacylglycerol accumulation thus may add additional insight into the regulation of phosphoinositide turnover and the complex actions of $\mathrm{Li}^{+}$. Key Words: Phosphoinositide turnover-Inositol phosphate-CDP-diacylglycerol--Rat brain. Heacock A. M. et al. Measurement of receptor-activated phosphoinositide turnover in rat brain: Nonequivalence of inositol phosphate and CDP-diacylglycerol formation. J. Neurochem. 60, 1087-1092 (1993).
The phosphoinositide signal transduction pathway in the CNS responds to the activation of any of a number of receptors that are distributed differentially throughout the brain (Fisher et al., 1992). Sustained formation of the second messengers inositol 1,4,5trisphosphate $\left(\mathrm{IP}_{3}\right)$ and diacylglycerol $(\mathrm{DAG})$ in response to receptor activation requires the continued resynthesis of phosphatidylinositol 4,5-bisphosphate $\left[\mathrm{PI}(4,5) \mathrm{P}_{2}\right]$ via the sequential phosphorylation of phosphatidylinositol (PI). DAG is metabolized via phosphatidic acid to the liponucleotide CDP-diacylglycerol (CDP-DAG), which, in the presence of inositol, is converted to PI in a reaction catalyzed by $\mathrm{PI}$ synthase (Agranoff et al., 1958; Paulus and Kennedy, 1960). The latter enzyme is reported to have a relatively low affinity for inositol (Benjamins and Agranoff, 1969; Ghalayini and Eichberg, 1985), and thus, under conditions where inositol concentrations are reduced, PI synthesis may be compromised. These considerations, together with the observation of uncompetitive inhibition by $\mathrm{Li}^{+}$of inositol monophos- phatase (Allison and Stewart, 1971), form the basis for an inositol depletion hypothesis to account for the psychotherapeutic action of $\mathrm{Li}^{+}$(Berridge et al., 1982, 1989). Evidence in support of this model of $\mathrm{Li}^{+}$action has been obtained recently in experiments in which labeled CDP-DAG was found to accumulate in carbachol-stimulated rat cerebral cortex slices in the presence of $\mathrm{Li}^{+}$(Godfrey, 1989; Kennedy et al., 1990). $\mathrm{Li}^{+}$ is thought to "trap" the labeled CDP-DAG indirectly by inducing a substantial decrease in intracellular inositol (a result of its block of inositol monophosphatase), thus preventing further metabolism of CDPDAG to PI. Whereas Godfrey (1989) also showed a $\mathrm{Li}^{+}$-dependent accumulation of labeled CDP-DAG in the presence of norepinephrine and serotonin, other agonists or brain regions were not investigated. For a given receptor, the extent of stimulation of radiolabeling of inositol phosphates (IP) would be expected to be predictive of the magnitude of radiolabeling of CDP-DAG. It seemed possible, in part because of the heterogeneity of the brain, that the relative magni-
Received July 6, 1992; revised manuscript received August 10, 1992; accepted August 17, 1992.

Address correspondence and reprint requests to Dr. A. Heacock at Neuroscience Laboratory, University of Michigan, 1103 E. Huron, Ann Arbor, MI 48104-1687, U.S.A.
Abbreviations used: CDP-DAG, CDP-diacylglycerol; DAG, diacylglycerol; IP, inositol phosphate(s); $\mathrm{IP}_{3}$, inositol 1,4,5-trisphosphate; PI, phosphatidylinositol; $\mathrm{PI}(4,5) \mathrm{P}_{2}$, phosphatidylinositol 4,5-bisphosphate. 
tudes of the CDP-DAG and IP responses might differ as a function of both receptor type and brain region. Such information might reveal a particular focus for the actions of $\mathrm{Li}^{+}$. Therefore, in the present study, the observations of Godfrey (1989) and Kennedy et al. (1990) were extended by examining the ability of agonists for six different phosphoinositide-linked receptors in different brain regions to elicit accumulation of CDP-DAG in parallel with that of IP. In cerebral cortex and hippocampus, activation of muscarinic receptors gave a good correspondence between these two measures of stimulated phosphoinositide turnover, whereas varying degrees of correspondence were obtained for other receptors.

\section{MATERIALS AND METHODS}

\section{Materials}

Carbamoylcholine (carbachol), arterenol (norepinephrine), histamine, cytidine diphosphate diglyceride (dipalmitoyl), cytidine, and $\left[5-{ }^{3} \mathrm{H}\right]$ cytidine $(15 \mathrm{Ci} / \mathrm{mmol})$ were purchased from Sigma Chemical Co. (St. Louis, MO, U.S.A.). $m y v-\left[2-{ }^{3} \mathrm{H}\right]$ Inositol $(15 \mathrm{Ci} / \mathrm{mmol})$ was obtained from Amersham Corp. (Arlington Heights, IL, U.S.A.). Serotonin was purchased from Research Biochemicals, Inc. (Natick, MA, U.S.A.). Quisqualic acid was from Cambridge Research Biochemicals (Wilmington, DE, U.S.A.), and endothelin-1 was a product of Peptides International (Louisville, KY, U.S.A.). Dowex $1 \times 8$ (100-200 mesh, formate form) was obtained from Bio-Rad (Rockville Centre, NY, U.S.A.).

\section{Measurement of labeled IP and CDP-DAG in brain slices}

Sprague-Dawley rats (13-18 days old) were killed by decapitation, and slices of cerebral cortex, hippocampus, or cerebellum $(350 \times 350 \mu \mathrm{m})$ were prepared on a Mcllwain tissue chopper. Tissue was then washed several times at $37^{\circ} \mathrm{C}$ in oxygenated buffer A $(142 \mathrm{~m} M \mathrm{NaCl}, 5.6 \mathrm{~m} M \mathrm{KCl}$, $2.2 \mathrm{~m} M \mathrm{CaCl}_{2}, 3.6 \mathrm{~m} M \mathrm{NaHCO}_{3}, 1 \mathrm{~m} M \mathrm{MgCl}_{2}, 5.6 \mathrm{~m} M$ glucose, and $30 \mathrm{~m} M$ HEPES, $\mathrm{pH}$ 7.4) and incubated, with shaking, in the same buffer for $60 \mathrm{~min}$ with one change of buffer after $30 \mathrm{~min}$. Tissue slices were then allowed to settle, and $50 \mu \mathrm{l}$ of gravity-packed slices $(0.8-1.2 \mathrm{mg}$ of protein) were transferred to flat-bottomed plastic minivials and incubated with $350 \mu \mathrm{l}$ of buffer A containing either $5 \mu \mathrm{Ci}$ of myo- $\left[2-{ }^{3} \mathrm{H}\right]$ inositol or $3 \mu \mathrm{Ci}$ of $\left[5-{ }^{3} \mathrm{H}\right]$ cytidine at $37^{\circ} \mathrm{C}$ for 60 min. $\mathrm{LiCl}$ was then added to a final concentration of $5 \mathrm{mM}$ $(50 \mu 1$ of $50 \mathrm{~m} M)$. In preliminary experiments, $5 \mathrm{~m} M \mathrm{LiCl}$ was found to be optimal for both IP and CDP-DAG accumulations. After $10 \mathrm{~min}, 100 \mu \mathrm{l}$ of buffer or agonist were added to duplicate tubes. Reactions were stopped after 30 min by addition of $1.7 \mathrm{ml}$ of chloroform/methanol $(1: 2$, $\mathrm{vol} / \mathrm{vol})$. Preliminary experiments indicated that formation of IP or CDP-DAG for all agonists in all three tissues remained approximately linear for at least $30 \mathrm{~min}$. For tissue labeled with [ $\left.{ }^{3} \mathrm{H}\right]$ inositol, total radioactivity in IP was determined following ion-exchange chromatography as described previously (Fisher et al., 1984; Heacock et al., 1987). Aliquots of the lower phases were also removed for determination of radioactivity in inositol phospholipids. Lipid labeling, in general, was unchanged by incubation with agonist. Where small increases did occur $(<20 \%)$, there was no apparent correlation with the extent of IP labeling, and thus the data presented are based on total disintegrations of IP per minute per tube, without correction for lipid labeling. For tissue labeled with $\left[{ }^{3} \mathrm{H}\right]$ cytidine, phases were separated by addition of $1 \mathrm{ml}$ of chloroform and $0.5 \mathrm{ml}$ of $1.2 \mathrm{M} \mathrm{HCl}$, and the lower phase was then washed twice with $2.0 \mathrm{ml}$ of acidified Folch theoretical upper phase containing $5 \mathrm{mM}$ cytidine. A 1-ml aliquot of the lower layer was then transferred to a scintillation vial and dried prior to measurement of radioactivity. Analysis of zero time control samples indicated that less than $2 \%$ of the basal chloroform-extractable radioactivity could have been due to contaminants in the radiolabeled precursor. Duplicate determinations of either ${ }^{3} \mathrm{H}$-IP or ${ }^{3} \mathrm{H}$-CDP-DAG differed by no more than $10 \%$. Data are expressed as percent stimulation above basal [(experimental - basal)/basal $\times 100$ ]. To verify the identity of radiolabeled CDP-DAG formed in the tissue slice incubations, samples of $\left[{ }^{3} \mathrm{H}\right]$ cytidine-labeled chloroform-soluble material were subjected to thin layer chromatography on oxalate-impregnated plates with the solvent chloroform/ acetone/methanol/acetic acid/water (40:15:13:12:8, by volume; Downes and Stone, 1986). Thin layer chromatographic analysis of both the basal and carbachol-stimulated $\left[{ }^{3} \mathrm{H}\right]$ cytidine-labeled lipid extracts from cerebellum and cortex indicated that $8-15 \%$ of the radioactivity remained at the origin, $72-85 \%$ comigrated with authentic CDP-DAG $\left(R_{\mathrm{f}}=0.41\right)$, and 3-6\% migrated more rapidly $\left(R_{\mathrm{f}}=0.66\right)$ and also increased with carbachol treatment. The identity of the latter component is unknown.

\section{Measurement of tissue inositol concentration}

A modification of the method of Mount and Laker (1981) was utilized. Intact dissected brain tissue or incubated tissue slices (1-2 mg of protein) were homogenized in deionized water, and then $1.5 \mathrm{ml}$ of chloroform/methanol $(1: 2, \mathrm{vol} /$ $\mathrm{vol}$ ) and $1 \mathrm{ml}$ each of chloroform and deionized water were added. Xylitol ( $50 \mu \mathrm{g} / \mathrm{sample})$ was included as an internal polyol standard. Following separation of phases, the aqueous upper phase was dried in vacuo and stored over phosphorus pentoxide for $30-60 \mathrm{~min}$ prior to acetylation. Dried samples were then treated with $0.5 \mathrm{ml}$ of distilled pyridine at $70^{\circ} \mathrm{C}$ for $30 \mathrm{~min}$, followed by the addition of 0.5 $\mathrm{ml}$ of acetic anhydride and incubation for $10 \mathrm{~min}$ at $70^{\circ} \mathrm{C}$. Samples were then vacuum-dried and stored over phosphorus pentoxide. Dried acetylated samples were dissolved in $10-20 \mu$ l of chloroform, and $2 \mu \mathrm{l}$ were applied to an SP 2330 capillary column of a Hewlett-Packard gas chromatograph. The peaks were then integrated, and the inositol values were corrected for recovery of the xylitol standard. Values are expressed as nanomoles per milligram of protein.

Protein was measured by the method of Geiger and Bess$\operatorname{man}(1972)$.

\section{PI synthase measurement}

Assay of PI synthase was carried out by a modification of the method of Fischl and Carman (1983). Tissue was homogenized in 9 volumes of $50 \mathrm{~m} M$ Tris- $\mathrm{HCl}, \mathrm{pH} 8.0,0.32$ $M$ sucrose, $1 \mathrm{~m} M$ EGTA, $0.5 \mathrm{~m} M$ dithiothreitol, and then centrifuged at $100,000 \mathrm{~g}$ for $60 \mathrm{~min}$. The membrane pellet was resuspended in the same buffer, and aliquots were incubated at $37^{\circ} \mathrm{C}$ for $30 \mathrm{~min}$ in a volume of $200 \mu$ with the following reagents (final concentration): $50 \mathrm{mM}$ Tris- $\mathrm{HCl}$ buffer, pH $8.0,1 \mathrm{~m} M$ EGTA, $0.1 \%$ Triton X-100, $3 \mathrm{~m} M$ $\mathrm{MnCl}_{2}, 20 \mathrm{~m} M \mathrm{MgCl}_{2}, 0.2 \mathrm{~m} M$ CDP-DAG [dipalmitoyl; chloroform/methanol (1:1) solution, dried under $\mathrm{N}_{2}$ and sonicated in buffer], and $0.1-10 \mu M\left[{ }^{3} \mathrm{H}\right]$ inositol $(10 \mu \mathrm{Ci} /$ 
$\mu \mathrm{mol})$. Reactions were stopped by addition of $1.7 \mathrm{ml}$ of chloroform/methanol (1:2) and acid-extracted, and then aliquots of the lower layer were dried in scintillation vials for determination of radioactivity.

\section{RESULTS}

\section{Comparison of IP and CDP-DAG responses}

The relative abilities of agonists for six phosphoinositide-linked receptors to elicit increases in accumulation of both IP and CDP-DAG were determined in three regions of 13-18-day rat brain (Fig. 1). This age was chosen to ensure optimal stimulation of phosphoinositide turnover by many of these agonists (Nicoletti et al., 1986; Heacock et al., 1987). The largest stimulations of ${ }^{3} \mathrm{H}$-IP formation were elicited by activation of endothelin (ET-1), glutamate (quisqualate), or muscarinic (carbachol) receptors, whereas activation of adrenergic (norepinephrine) and histaminergic (histamine) receptors was less effective (see Fig. 1). Measurement of ${ }^{3} \mathrm{H}-\mathrm{CDP}-\mathrm{DAG}$ accumulation revealed a very different pattern. The best correspondence between these two measures of stimulated phosphoinositide turnover was exhibited for the response to activation of the muscarinic receptor in cortex and hippocampus by carbachol. In contrast, for the cerebellum, the IP and CDP-DAG responses to carbachol were less well correlated. The cerebellum also differed from the other two brain regions in that it exhibited fourfold higher basal levels of ${ }^{3} \mathrm{H}-\mathrm{CDP}$ DAG labeling (legend to Fig. 1). The dose-response curve for stimulation of IP formation by carbachol in the cerebral cortex closely resembled that for accumulation of CDP-DAG (data not shown), with $\mathrm{EC}_{50}$ values of $100 \mu M$ and $85 \mu M$, respectively. Inclusion of $10 \mu M$ atropine blocked both responses to $1 \mathrm{~m} M$ carbachol by $98-99 \%$, while having no effect on basal ${ }^{3} \mathrm{H}-\mathrm{IP}$ or ${ }^{3} \mathrm{H}-\mathrm{CDP}-\mathrm{DAG}$ formation. The other agonists examined exhibited lesser degrees of correspon- dence between the two assays, with the extreme exemplified by endothelin-1, which gave a large IP response in all three brain regions, but elicited increases in CDP-DAG of only 8-12\% above basal. For the glutamate analogue quisqualic acid, a possible indirect effect on ${ }^{3} \mathrm{H}-\mathrm{IP}$ accumulation, mediated by the ionotropic rather than the metabotropic glutamate receptor, was explored. In agreement with most previous reports (Recasens et al., 1988; Godfrey and Taghavi, 1990; Schoepp and Hillman, 1990; but see also Baird et al., 1991), the ionotropic glutamate receptor antagonists, 6-nitro-7-cyanoquinoxaline-2,3-dione and 6,7dinitroquinoxaline-2,3-dione (Honoré et al., 1988), were found to have no effect on the IP response elicited by quisqualic acid in any of the three brain regions examined (data not shown).

In a more limited series of experiments, the responses to serotonin in cerebral cortex were also examined. Serotonin, at $100 \mu M$, increased labeling of IP by $116 \pm 45 \%(n=4)$, whereas ${ }^{3} \mathrm{H}-\mathrm{CDP}-\mathrm{DAG}$ increased, in a $\mathrm{Li}^{+}$-dependent manner, by $84 \pm 17 \%$ ( $\mathrm{n}$ $=4$ ). Threefold larger increases in the latter (but not the former) were obtained with $1 \mathrm{~m} M$ serotonin; however, this was determined to be a nonreceptor-mediated, $\mathrm{Li}^{+}$-independent effect, which could be mimicked by other structurally similar cationic amphiphilic compounds (Hauser and Eichberg, 1975; Eichberg et al., 1979).

The possibility that the observed differential CDPDAG responses may reflect differences in $\left[{ }^{3} \mathrm{H}\right]$ cytidine uptake or in intracellular cytidine or cytidine nucleotide content was considered. If the robust CDP-DAG response to carbachol was an artifact due to increased specific activity of cytidine pools in the environment of the muscarinic receptors, then addition of increasing amounts of unlabeled cytidine might be expected to reduce the response. Such was not the case, because addition of 1,10 , or $30 \mu M$ cytidine to cerebral cortex slices, although reducing the
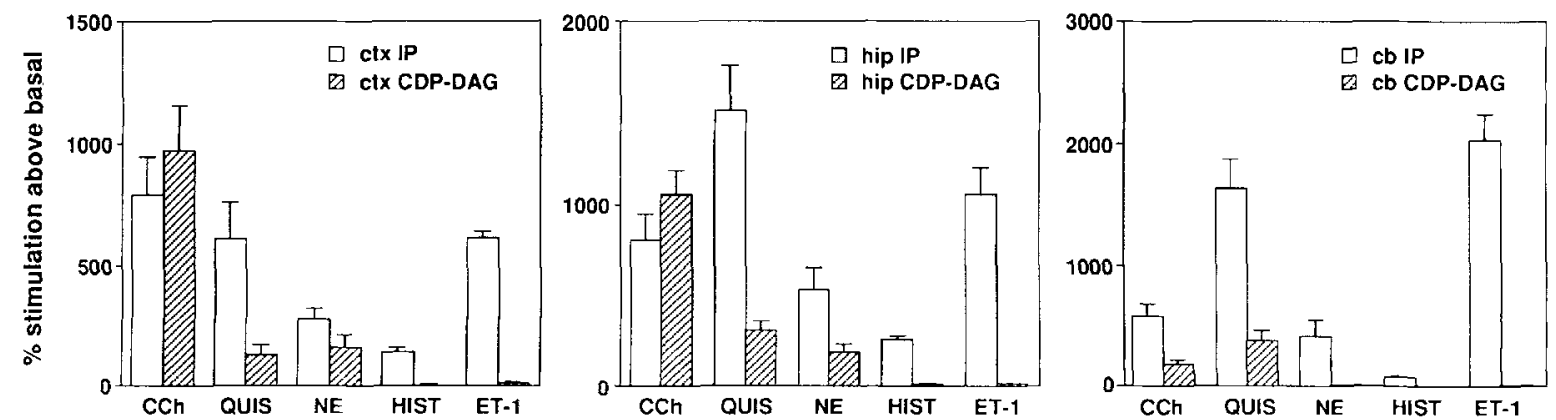

FIG. 1. Comparison of IP and CDP-DAG responses. Slices of cortex, hippocampus, or cerebellum from 13-18-day rats were prelabeled with $\left.{ }^{3} \mathrm{H}\right]$ inositol or $\left[{ }^{3} \mathrm{H}\right]$ cytidine, as described in Materials and Methods, and then incubated with the indicated concentrations of agonists for $30 \mathrm{~min}$ in the presence of $5 \mathrm{mM} \mathrm{LiCl}$. Radioactivity in IP or CDP-DAG was then determined. Data are expressed as percent stimulation above basal (means \pm SEM) for the number of experiments indicated below. Basal values for a typical experiment for cortex (ctx), hippocampus (hip), and cerebellum (cb) were 3,735, 6,566, and 5,682 dpm for IP and 4,259, 4,195, and 16,186 dpm for CDP-DAG, respectively. Agonists were used at or above their maximally effective concentrations for stimulation of phosphoinositide turnover. The concentrations and number of experiments for each agonist are as follows: carbachol (CCh; $1 \mathrm{mM}, \mathrm{n}=6$ ), quisqualate (QUIS; $100 \mu M, n$ $=5$ ), norepinephrine ( $N E ; 100 \mu M, n=3)$, histamine (HIST; $1 \mathrm{mM}, \mathrm{n}=4$ ), and endothelin-1 $(\mathrm{ET}-1 ; 0.5 \mu M, \mathrm{n}=4$ ). 
radioactivity associated with CDP-DAG by 28,74 , and $90 \%$, respectively, resulted in carbachol-stimulated CDP-DAG labeling of $1,410,1,330$, and $1,520 \%$. Neither did addition of carbachol have any effect on labeling of cytidine nucleotides as determined by measurement of water-soluble $\left[{ }^{3} \mathrm{H}\right]-$ cytidine-labeled material bound to and then eluted from Dowex-formate columns (data not shown).

\section{Effect of $\mathrm{Li}^{+}$and reversibility by inositol}

The dependence on the presence of $\mathrm{LiCl}$ for stimulated formation of both IP and CDP-DAG was examined. In cerebral cortex, basal IP and CDP-DAG labeling were both reduced by approximately $20 \%$ in the absence of $\mathrm{Li}^{+}$. Omission of $\mathrm{Li}^{+}$resulted in a $77-85 \%$ reduction in the stimulated IP formation elicited by all five agonists, in all three brain regions, when compared with the maximum values obtained in the presence of $5 \mathrm{mM} \mathrm{\textrm {Li } ^ { + }}$. Stimulation of ${ }^{3} \mathrm{H}-\mathrm{CDP}-\mathrm{DAG}$ accumulation by carbachol, quisqualate, and norepinephrine showed an even greater dependence upon $\mathrm{Li}^{+}$, with a $97-100 \%$ reduction in its absence. The effect of $\mathrm{Li}^{+}$omission on the small histamine and endothelin CDP-DAG responses was not examined.

The ability of inositol to reverse the agonist-induced or basal accumulation of CDP-DAG in cerebral cortex was then explored. A concentration-dependent reduction in ${ }^{3} \mathrm{H}-\mathrm{CDP}-\mathrm{DAG}$ accumulation was observed upon addition of inositol for all three agonists examined (Fig. 2), with $\mathrm{EC}_{50}$ values for inositol of $0.6-1.5 \mathrm{~m} M$, values similar to those previously reported for reversal of the carbachol response (Godfrey, 1989; Kennedy et al., 1990). Reversal of the basal ${ }^{3} \mathrm{H}$-CDP-DAG accumulation (Fig. 2, inset) required nearly 10 -fold less inositol $\left(\mathrm{EC}_{50}=0.17 \pm 0.1\right.$

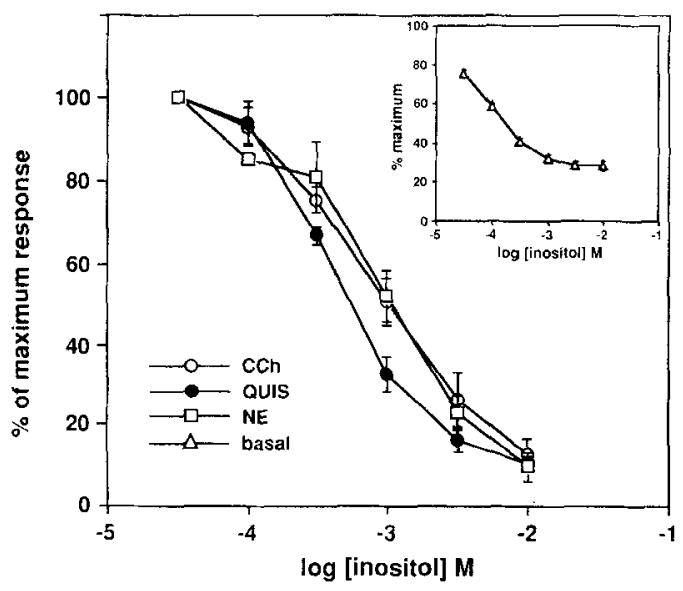

FIG. 2. Inositol reversal of CDP-DAG accumulation in rat cerebral cortex slices. Experiments were carried out as in Fig. 1, using the same concentrations of agonists, except that the indicated concentrations of inositol were added together with the $\mathrm{Li}^{+}$after the 60 -min prelabeling period. The inositol $\mathrm{EC}_{50}$ values were as follows: carbachol (CCh; $1.5 \pm 0.3 \mathrm{mM}, n=6$ ); quisqualate (QUIS; $0.64 \pm 0.07 \mathrm{mM}, \mathrm{n}=4$ ); norepinephrine (NE; $1.1 \pm 0.2 \mathrm{mM}, \mathrm{n}$ $=4)$. Inset: Inositol reversal of basal ${ }^{3} \mathrm{H}$-CDP-DAG accumulation.
TABLE 1. Inositol content of rat brain regions

\begin{tabular}{lcc}
\hline & Intact tissue & Incubated slices \\
\hline Cortex & $22.7 \pm 0.3$ & $8.2 \pm 0.2$ \\
Hippocampus & $30.3 \pm 0.9$ & $11.5 \pm 0.8$ \\
Cerebellum & $38.3 \pm 0.9$ & $17.0 \pm 1.0$ \\
\hline
\end{tabular}

Tissue dissected from 15-day rat brain was homogenized immediately or sliced and incubated for $2.5 \mathrm{~h}$ at $37^{\circ} \mathrm{C}$ in the absence of $\mathrm{Li}^{+}$, as described in Materials and Methods. Incubated slices were then pelleted and homogenized, and the inositol content and protein concentration determined. Data, given in $\mathrm{nmol} / \mathrm{mg}$ of protein, are expressed as means $\pm \operatorname{SEM}(\mathrm{n}=3)$ for one of two experiments, which gave similar results.

$\mathrm{m} M, \mathrm{n}=10$ ). Of relevance to interpreting these requirements for inositol is the inositol concentration of the incubated brain slices and the kinetic properties of PI synthase. The latter is reported to have a $K_{\mathrm{m}}$ for inositol of 1.5-4.6 $\mathrm{mM}$ (Benjamins and Agranoff, 1969; Ghalayini and Eichberg, 1985). Determination of the inositol concentration dependence of PI synthase in a crude particulate fraction from rat cortex indicated a $K_{\mathrm{m}}$ of $0.91 \pm 0.04 \mathrm{~m} M$ (mean \pm SEM, n $=3$ ), similar to the values obtained for the $\mathrm{EC}_{50}$ for inositol reversal of agonist-stimulated CDP-DAG accumulation (Fig. 2). Preparation of slices from adult rat cortex is reported to result in an $80 \%$ loss of tissue inositol content (Sherman et al., 1986). Therefore, measurements of inositol in incubated brain slices were carried out and the values compared to those for intact tissue (Table 1). The inositol concentration in 15-day rat brain regions $(2-4 \mathrm{~m} M)$ was less than that reported for whole adult rat brain (5-6 $\mathrm{mM}$; Sherman et al., 1977, 1986). This appears to be a developmental difference rather than a loss of inositol due to the dissection procedure, because the same procedure applied to adult rat brain gave values in agreement with those previously found for whole brain (Stubbs and Agranoff, unpublished observations). Following incubation of slices prepared from 15-day brain regions, inositol content was reduced by $56-64 \%$. The concentration of inositol in incubated cerebral cortex slices may be approximated at $1 \mathrm{~m} M$ or less, a value which is in agreement with both the $K_{\mathrm{m}}$ for inositol of PI synthase and the $\mathrm{EC}_{50}$ for inositol reversal of $\mathrm{Li}^{+}$-sensitive CDP-DAG formation.

\section{DISCUSSION}

Activation of phosphoinositide-linked receptors results in the hydrolysis of $\mathrm{PI}(4,5) \mathrm{P}_{2}$ to yield equivalent amounts of $\mathrm{IP}_{3}$ and DAG. The widely used $\left[{ }^{3} \mathrm{H}\right]-$ inositol-labeling technique (Berridge et al., 1982) permits rapid assessment of phosphoinositide turnover by quantitatively trapping inositol monophosphates, degradation products of $\mathrm{IP}_{3}$, in the presence of $\mathrm{Li}^{+}$. A method for indirectly assessing DAG formation was provided by the demonstration by Downes and Stone 
(1986), in parotid gland, of a carbachol-stimulated, $\mathrm{Li}^{+}$-dependent accumulation of ${ }^{32} \mathrm{P}_{\mathrm{i}}$ or $\left[{ }^{3} \mathrm{H}\right]$ cytidinelabeled CDP-DAG. These observations, as well as the studies of Godfrey (1989) and Kennedy et al. (1990), provide not only an alternative technique for measurement of phosphoinositide turnover, but also lend support to the inositol depletion hypothesis as a mechanism for the psychotherapeutic actions of $\mathrm{Li}^{+}$. In the present study, the extent of correlation between these two measures of phosphoinositide turnover for different receptors and brain regions was explored. The ratios of the IP to CDP-DAG responses would be expected to be rather uniform, although not necessarily unity, because neither response would accurately reflect chemical mass due to lack of isotopic equilibrium in the brain slice preparation. In contrast to this expectation, the extent of correlation between these two measures of phosphoinositide turnover was found to be quite variable in all three brain regions examined. For example, if the ratio of the CDP-DAG to IP responses for the muscarinic receptor in cerebral cortex is normalized to 1.0 , then the relative ratios for the following receptors are as follows: serotonin, 0.7; norepinephrine, 0.4; glutamate, 0.16 ; histamine, 0.02 ; and endothelin, 0.01 . These results for carbachol, norepinephrine, and serotonin are in general agreement with those reported by Godfrey (1989) for this brain region. From the data presented here, it appears that the ${ }^{3} \mathrm{H}-\mathrm{CDP}-\mathrm{DAG}$ assay method may not be so widely applicable as the ${ }^{3} \mathrm{H}$-IP method for assessment of stimulation of inositol lipid turnover. In addition, the present results also suggest limitations to the utility of the CDP-DAG-based autoradiographic method for localization of receptor-mediated phosphoinositide turnover in brain (Hwang et al., 1990). Although further interpretation of these results must remain tentative due to the likely presence of multiple pools of these inositol lipid metabolites and to the absence of mass data for CDP-DAG or IP, the inability of endothelin and histamine to elicit a ${ }^{3} \mathrm{H}$ CDP-DAG response suggests that the DAG formed from $\mathrm{PI}(4,5) \mathrm{P}_{2}$ hydrolysis is not being efficiently trapped as CDP-DAG. Inefficient trapping of DAG as CDP-DAG may occur for any of a number of reasons, including an alternative metabolic fate for DAG or phosphatidic acid, a high inositol content in the vicinity of these receptors, or the existence of a PI synthase with a relatively low $K_{\mathrm{m}}$ for inositol (Imai and Gershengorn, 1987). Thus far, no CDP-DAG response has been obtained in the absence of an IP response. That the converse is true (i.e., for endothelin and histamine) suggests that the use of these two assays in combination may provide more insight into the regulation of phosphoinositide turnover and the effects of $\mathrm{Li}^{+}$on this signal transduction pathway than either alone.

Acknowledgment: We thank Evan Stubbs for his help with the inositol determinations, JoAnn Kelsch and Stephanie McWethy for excellent secretarial assistance, and Ste- phen K. Fisher for his insightful comments. This work was supported by NIMH grant MH 42652 (A.M.H.), NIH grant NS 15413 (B.W.A.), and a grant from the Herbert H. and Grace A. Dow and Harry A. and Margaret D. Towsley Foundations (B.W.A.).

\section{REFERENCES}

Agranoff B. W., Bradley R. M., and Brady R. O. (1958) The enzymatic synthesis of inositol phosphatide. J. Biol. Chem. 233, 1077-1083.

Allison J. H. and Stewart M. A. (1971) Reduced brain inositol in lithium-treated rats. Nature 233, 267-268.

Baird J. G., Challiss A. J., and Nahorski S. R. (1991) Role for ionotropic and metabotropic receptors in quisqualate-stimulated inositol polyphosphate accumulation in rat cerebral cortex. Mol. Pharmacol. 39, 745-753.

Benjamins J. A. and Agranoff B. W. (1969) Distribution and properties of CDP-diglyceride:inositol transferase from brain. $J$. Neurochem. 16, 513-527.

Berridge M. J., Downes C. P., and Hanley M. R. (1982) Lithium amplifies agonist-dependent phosphatidylinositol responses in brain and salivary glands. Biochem. $J$. 206, 587-595.

Berridge M. J., Downes C. P., and Hanley M. R. (1989) Neural and developmental actions of lithium: a unifying hypothesis. Cell 59, 411-419.

Downes C. P. and Stone M. A. (1986) Lithium-induced reduction in intracellular inositol supply in cholinergically stimulated parotid gland. Biochem. J. 234, 199-204.

Fichberg J., Gates J., and Hauser G. (1979) The mechanism of modification by propranolol of the metabolism of phosphatidyl-CMP (CDP-diacylglycerol) and other lipids in the rat pineal gland. Biochim. Biophys. Acta 573, 90-106.

Fischl A. S. and Carman G. M. (1983) Phosphatidylinositol biosynthesis in Saccharomyces cerevisiae: purification and properties of microsome-associated phosphatidylinositol synthase. $J$. Bacteriol. 154, 304-311.

Fisher S. K., Figueiredo J. C., and Bartus R. T. (1984) Differential stimulation of inositol phospholipid turnover in brain by analogs of oxotremorine. $J$. Neurochem. 43, 1171-1179.

Fisher S. K., Heacock A. M., and Agranoff B. W. (1992) Inositol lipids and signal transduction in the nervous system: an update. $J$. Neurochem. 58, 18-38.

Geiger P. J. and Bessman S. P. (1972) Protein determination by Lowry's method in the presence of sulfhydryl reagents. Anal. Biochem. 49, 467-473.

Ghalayini A. and Eichberg J. (1985) Purification of phosphatidylinositol synthetase from rat brain by CDP-diacylglycerol affinity chromatography and properties of the purified enzyme. $J$. Neurochem. 44, 175-182.

Godfrey P. P. (1989) Potentiation by lithium of CMP-phosphatidate formation in carbachol-stimulated rat cerebral-cortical slices and its reversal by myo-inositol. Biochem. J. 258, 621624.

Godfrey P. P. and Taghavi Z. (1990) The effect of non-NMDA antagonists and phorbol esters on excitatory amino acid stimulated inositol phosphate formation in rat cerebral cortex. Nettrochem. Int. 16, 65-72.

Hauser G. and Eichberg J. (1975) Identification of cytidine diphosphate-diglyceride in the pineal gland of the rat and its accumulation in the presence of DL-propranolol. J. Biol. Chem. 250, 105-112.

Heacock A. M., Fisher S. K., and Agranoff B. W. (1987) Enhanced coupling of neonatal muscarinic receptors in rat brain to phosphoinositide turnover. $J$. Neurochem 48, 1904-1911.

Honoré T., Davies S. N., Drejer J., Fletcher E. J., Jacobsen P., Lodge D., and Nielsen F. E. (1988) Quinoxalinediones: potent competitive non-NMDA glutamate receptor antagonists. Science 241, 701-703. 
Hwang P. M., Bredt D. S., and Snyder S. H. (1990) Autoradiographic imaging of phosphoinositide turnover in the brain. Science 249, 802-804.

Imai A. and Gershengorn M. C. (1987) Independent phosphatidy]inositol synthesis in pituitary plasma membrane and endoplasmic reticulum. Nature 325, 726-728.

Kanoh H., Yamada K., and Sakane F. (1990) Diacylglycerol kinase: a key modulator of signal transduction. Trends Biochem. Sct. 15, 47-50.

Kennedy E. D., Challiss R. A. J., Ragan C. I., and Nahorski S. R. (1990) Reduced inositol polyphosphate accumulation and inositol supply induced by lithium in stimulated cerebral cortex slices. Biochem. J. 267, 781-786.

Mount J. N. and Laker M. F. (1981) Estimation of sugar alcohols by gas-liquid chromatography using a modified acetylation procedure. J. Chromatogr. 226, 191-197.

Nicoletti F., Iadarola M. J., Wroblewski J. T., and Costa E. (1986) Excitatory amino acid recognition sites coupled with inositol phospholipid metabolism: developmental changes and inter- action with $\alpha_{1}$-adrenoreceptors. Proc. Natl. Acad. Sci. USA 83, 1931-1935.

Paulus H. and Kennedy E. P. (1960) The enzymatic synthesis of inositol monophosphatide. J. Biol. Chem. 235, 1303-1311.

Recasens M., Guiramand J., Nourigat A., Sassetti I., and Devilliers G. (1988) A new quisqualate receptor subtype $\left(\mathrm{sAA}_{2}\right)$ responsible for the glutamate-induced inositol phosphate formation in rat brain synaptoneurosomes. Neurochem. Int. 13, 463-467.

Schoepp D. D. and Hillman C. C. Jr. (1990) Developmental and pharmacological characterization of quisqualate, ibotenate, and trans-1-amino-1,3-cyclopentanedicarboxylic acid stimulations of phosphoinositide hydrolysis in rat cortical brain slices. Biogenic Amines 7, 331-340.

Sherman W. R., Packman P. M., Laird M. H., and Boshans R. L. (1977) Measurement of myo-inositol in single cells and defined areas of the nervous system by selected ion monitoring. Anal. Biochem. 78, 119-131.

Sherman W. R., Gish B. G., Honchar M. P., and Munsell L. Y. (1986) Effects of lithium on phosphoinositide metabolism in vivo. Fed. Proc. 45, 2639-2646. 